\title{
Emerging Brominated Flame Retardants in Sediments and Soils: a Review
}

\author{
$\operatorname{Urs~Jans~}^{1,2}$ (D)
}

Published online: 24 September 2016

(C) Springer International Publishing AG 2016

\begin{abstract}
Brominated flame retardants (BFRs) are an important class of commercial chemicals used in a wide variety of products. Several established BFRs are being phased out and replaced with new compounds that are often also brominated. These compounds are so-called emerging BFRs. Very little is known about these emerging BFRs. The analysis of these emerging compounds in environmental samples can provide valuable insight into their environmental behavior. This review summarizes the studies reporting the analysis of emerging BFRs in sediment and soil samples from 2012 to 2015. A list of the different emerging BFRs detected in sediment and soil samples along with their structure is shown. In addition, the different extraction methods used for sediments and soil samples, the various clean-up methods of the sample extracts, and the instrumental analytical techniques are presented.
\end{abstract}

Keywords Emerging brominated flame retardant - Sediment . Soil

\section{Introduction}

Fire safety legislation in the 1970 s greatly stimulated the discovery, production, and application of flame retardants. A

This article is part of the Topical Collection on Sediment and Other Pollutions

Urs Jans

ujans@ccny.cuny.edu

1 Department of Chemistry and Biochemistry, City College of New York, 160 Convent Ave, New York, NY 10031, USA

2 Ph. D. Program in Chemistry, The Graduate Center of the City University of New York, New York, NY 10016, USA major class of organic flame retardants is the class of brominated flame retardants (BFRs) [1]. BFRs are important commercial chemicals that are added to many consumer and commercial products. Typical uses are in polyurethane foam, plastics used in electronic and electric equipment, circuit boards, expanded and extruded plastic (e.g., styrofoam), textiles in furniture, various textiles used in public environments (e.g., curtains, carpets), wire coating, etc. The addition of the BFRs inhibits the products from burning when exposed to a spark or a smoldering cigarette. The State of California issued a flammability standard (Technical Bulletin 117, TB117) in 1975 establishing how much time a piece of upholstered furniture must withstand the exposure to a smoldering cigarette or a flame. As a consequence, manufacturers added BFRs to many of their products. Although it was a Californian regulation, manufactures often sold TB117-compliant products across the USA and Canada to avoid maintaining a double inventory. TB117 also encouraged flame retardant use in many other products than upholstered furniture. Many countries followed suit and have now enacted legislation requiring higher fire safety standards.

Most BFRs are additives that are mixed directly into the product during the synthesis of the polymer (e.g., foam, plastic). Additive BFRs do no directly react with the polymer molecules. Since they are not covalently bound to the material, they can escape the material and can be released into the environment $[2,3]$. In general, most additive BFRs are hydrophobic (e.g., large octanolwater partitioning constant, $\mathrm{K}_{\mathrm{ow}}$ ) and have a low vapor pressure. Compounds with such physical properties tend to associate well with particles and accumulate in lipids $[4,5]$. Alternatively, some BFRs are reactive. These reactive BFRs bind covalently to the polymer during the polymerization process. Therefore, these flame retardants are chemically bound to the polymer and thus are less likely 
to migrate out of the material and less likely to enter the environment than additive BFRs.

There are three main groups of so-called conventional BFRs that have been introduced several decades ago and have been used in many products. These three groups are polybrominated diphenylethers (PBDEs), hexabromocyclododecanes (HBCDDs), and tetrabromobisphenol A (TBBPA). Due to their widespread use over the past couple of decades, these three conventional groups of BFRs have been reported frequently in environmental samples. Restrictions have been issued on the use of PBDEs and HBCDDs by the USA and the European Union [1, 6], as a consequence additional BFRs have been introduced into consumer products and are now also reported to be present in a wide variety of biological samples (e.g., bird eggs, fish, blood, feces) and non-biological samples (e.g., aerosol particles, house dust, soil, sediment). Soils and sediments are known to be a final sink for persistent and bioaccumulative compounds such as polychlorinated biphenyls (PCBs) or PBDEs. Since most emerging additive BFRs have similar physical properties to known persistent and bioaccumulative compounds, it is anticipated that soils and sediments are also important sinks for emerging BFRs. Soil and sediment analyses have the potential to reveal which emerging BFRs are persistent and thus might pose an environmental problem in the long run.

The first review of BFRs was published in 1995 summarizing the findings on PBDEs and polybrominated biphenyls (PBBs) [7]. This initial review was followed by a review in 2002 that also included a discussion about the findings on TBBPA and HBCDDs [8]. Many important reviews followed. These initial reviews provided updates on this class of compounds [9-19]. It is the intention of this paper to compile and review the findings on emerging BFRs in sediments and soil that were published from 2013 to 2015. A summary of the compounds detected in sediment and soil is reported as well as a summary of the analytical methods that are used to determine the concentration of BFRs in sediment and soil samples.

\section{New Generation of BFRs Due to Restrictions and Regulations}

Of the first generation of BFRs, the PBBs were launched in 1970 [20, 21]. The production of PBBs halted in the USA by the end of 1974, and PBDEs were introduced as a new generation of BFRs [22, 23]. PBDEs were widely marketed, and by 200167,000 tons per year were sold worldwide [24]. Once it was apparent that PBDEs are accumulating in the environment and in humans, its production was ceased in the USA by 2013 [25] and other flame retardants were used instead. The United Nations also plays an important role in the regulation of PBDEs and HBCDDs through the "Stockholm Convention on Persistent Organic Pollutants" of the UNEP, the United Nations' Environment Programme. The Stockholm Convention designated the main ingredients of the pentaBDE and octaBDE mixtures as persistent organic pollutants (POPs) in 2009 ceasing their production in all countries that signed the convention. There are currently 179 countries part of the Stockholm convention; some non-ratifying countries include the USA, Italy, Malaysia, and Israel [26]. Regional and international regulations have also been implemented on the use of HBCDDs. In 2013, the Stockholm Convention designated HBCDDs as POPs. However, an important exception was made for the production and use of HBCDDs in expanded and extruded polystyrene [27]. Due to these restrictions and regulations on PBDEs and HBCDDs, other flame retardants have been considered and developed to replace PBDEs and HBCDDs [28].

\section{Types of BFRs and Current Uses}

In the following summary of established and emerging BFRs detected in sediment and soil the abbreviation standards introduced by Bergman et al. are followed [29]. The structures of the compounds can be found in Fig. 1.

Decabromodiphenyl ethane (DBDPE) was introduced as a replacement for BDE-209 and has been on the market for more than 20 years. DBDPE has been sold under the trade names Saytex 8010 (Albemarle Corp.) and Firemaster 2100 (Chemtura Corp.) [30]. DBDPE is not acutely toxic to humans [3]. However, Nakari and Huhtala report that DBDPE is acutely toxic to water fleas (Daphnia magna) and has damaging effects on the reproduction physiology of zebrafish (Danio rerio) [31].

Tribromophenoxy flame retardants is a group of flame retardants that includes five compounds that are structurally related. 1,3-Bis(2,4,6-tribromophenoxy)ethane (BTBPE), 2,3-dibromopropyl-2,4,6-tribromophenyl ether (TBPDBPE), 2-allyl-2,4,6-tribromophenyl ether (TBP-AE), 2bromoallyl 2,4,6-tribromophenyl ether (BATE), and 2,4,6tribromoanisol (TBA). These five compounds are all derived from 2,4,6-tribromophenol (TBP). BTBPE is synthesized by the reaction of two molecules of TBP with one molecule of 1,2-dibromoethane [32]. BTBPE was launched as a replacement for octaBDE and was marketed under the brand name FF 680 or Firemaster 680. It is used in acrylonitrile-butadiene styrene copolymers (ABS), high impact polystyrenes (HIPS), and in electronics (e.g., computers, television sets) [33]. BTBPE has been first reported in air particulates in 1979 [34] and then more frequently also in ambient air, indoor air, and lake sediments since the early 2000s [35, 36]. BTBPE shows low acute toxicity in model organisms (e.g., rats, dogs) [3]. BTBPE may cause antiestrogenic effects [37]. An association between BTBPE concentration in house dust and the hormone levels in men suggests exposure to BTBPE might 
<smiles>Brc1ccc(Oc2ccc(Br)c(CCc3c(Br)c(Br)c(Br)c(Br)c3Br)c2Br)cc1</smiles>

polybrominated biphenylether decabromodiphenylethane (PBDE)<smiles>CCCCC(CC)COC(=O)c1cc(Br)c(Br)c(Br)c1Br</smiles>

2-ethylhexyl tetrabromobenzoate (EH-TBB) bis(2-ethylhexyl) tetrabromophthalate (BEH-TEBP)<smiles>Brc1cc(Br)c(OCCOc2c(Br)cc(Br)cc2Br)c(Br)c1</smiles>

1,2-bis(2,4,6-tribromophenoxy)ethane (BTBPE)<smiles>BrCC(Br)COc1c(Br)cc(Br)cc1Br</smiles>

2,3-dibromopropyl-2,4,6-tribromphenyl ether (TBP.DBPE)<smiles>C=CCOc1c(Br)cc(Br)cc1Br</smiles>

2-allyl-1,3,5-tribromobenzene (TBP-AE)<smiles>C=C(Br)COc1c(Br)cc(Br)cc1Br</smiles>

2-bromoallyl-2,4,6-tribromphenyl ether (BATE)<smiles>Oc1c(Br)cc(Br)cc1Br</smiles>

2,4,6-tribromophenol (TBP)<smiles>COc1c(Br)cc(Br)cc1Br</smiles>

2,4,6-tribromoanisol (TBA)<smiles>Brc1c(Br)c(Br)c(Br)c(Br)c1Br</smiles>

hexabromobenzene (HBB)<smiles>Brc1cc(Br)cc(Br)c1</smiles>

1,3,5-tribromobenzene (TrBB)<smiles>Brc1cc(Br)c(Br)cc1Br</smiles>

1,2,4,5-tetrabromobenzene (TeBB)<smiles>Cc1c(Br)c(Br)c(Br)c(Br)c1Br</smiles>

pentabromotoluene (PBT)<smiles>Cc1c(Br)c(Br)c(C)c(Br)c1Br</smiles>

tetrabromop-xylene (TBX)<smiles>CCc1c(Br)c(Br)c(Br)c(Br)c1Br</smiles>

pentabromoethylbenzene (PBEB)<smiles>CC(C)(c1cc(Br)c(O)c(Br)c1)c1cc(Br)c(O)c(Br)c1</smiles>

tetrabromobisphenol A (TBBPA)<smiles>COc1c(Br)cc(C(C)(C)c2cc(Br)c(OC)c(Br)c2)cc1Br</smiles>

tetrabromobisphenol A bismethyl ether (TBBPA-BME)<smiles>CC(C)(c1cc(Br)c(OCC(Br)CBr)c(Br)c1)c1cc(Br)c(OCC(Br)CBr)c(Br)c1</smiles>

tetrabromobisphenol A bis(2,3-dibromopropyl)ether (TBBPA-BDBPE)<smiles>BrCC(Br)C1CCC(Br)C(Br)C1</smiles>

dibromoethyl-dibromocyclohexane (DBE-DBCH)<smiles>BrC1CCC(Br)C(Br)CCC1Br</smiles>

tetrabromocyclooctane (TBCO)<smiles>BrC(Br)CCC(Br)C(Br)CCC(Br)C(Br)CCC(Br)Br</smiles>

hexabromocyclododecane (HBCDD)<smiles>O=P(OCC(Br)CBr)(OCC(Br)CBr)OCC(Br)CBr</smiles>

tris(2,3-dibromopropyl) phosphate (TDBPP)<smiles>ClC1=C(Cl)C2(Cl)C3CCC(Br)C(Br)CCC3C1(Cl)C2(Cl)Cl</smiles>

dibromodecahydromethanobenzocyclooctene (DBHCTD)<smiles>ClC1=C(Cl)C2(Cl)C3CC(C(Br)C3Br)C2(Cl)C1(Cl)Cl</smiles>

dibromoaldrin (DBALD)<smiles>ClC1C(Br)C(Br)C(Br)C(Br)C1Br</smiles>

pentabromochloro- tribromotrichlorocyclocyclo-hexane $(\mathrm{PeBCCH})$ hexane $(\mathrm{TrBTrCCH})$

Fig. 1 Structures of established and emerging brominated flame retardants 
lead to the disruption of thyroid hormonal signals [38]. TBPDBPE was sold under the name Bromkal 73-5PE by the German company Chemische Fabrik Kalk. It was used in extrusion material for polypropylene (PP) and as an additive to ABS [39]. TBP-AE is sold under the brand names PHE-65 (Chemtura Corp.), Pyroguard FR100 among others. The compound is either used as reactive BFR when it is incorporated at the stage of polymerization, or just as additive BFR, mainly in expanded polystyrene (EPS) and polystyrene foam [40]. BATE is a degradation product of TBP-DBPE formed by the elimination of $\mathrm{HBr}$ [39]. TBP is marketed under various trade names (PH-73FF, FR-613). TBP is reported to disrupt hormonal regulation [41]. TBP has additional applications. It is also used as (i) a germicidal and antiseptic agent, (ii) a fungicide in wood treatment, and (iii) as a monomer for the synthesis of BTPBE, TBP-DBPE, and TBP-AE. TBP is also a likely degradation product of these same BFRs, such as TBP-DBPE [40]. In addition, TBA is reported to be produced naturally by microorganisms in the marine environment [42].

2-Ethyl-1-hexyl 2,3,4,5-tetrabromobenzoate (EH-TBB) mixed with bis(2-ethyl-1-hexyl)tetrabromophthalate (BEHTEBP) is used as an additive BFR and is produced by Chemtura Corp. under the name Firemaster 550. It is used in polyurethane foam (PUF) applications [43]. BEH-TEBP is also used as an additive BFR in polyvinyl chloride (PVC) and neoprene $[44,45]$. BEH-TEBP is suspected to be an endocrine disrupter. A positive correlation between BEH-TEBP levels in dust and triiodothyronine levels in exposed men was observed. This might suggest endocrine disrupting properties of BEH-TEBP [38].

Brominated benzenes comprise another group of structurally related BFRs that are currently in use. Brominated benzenes are considered older BFRs. Little is known about their current production volume. It is assumed to be low; however, it is possible that these compounds might have been reintroduced to the market in recent years [46]. Hexabromobenzene (HBB) is used as an additive flame retardant in paper, textiles, electronics, and plastics [40]. HBB is also suspected to be formed during the chemical decomposition of other BFRs such as PBDEs [47]. HBB is reported to be metabolized in the liver of rats to $1,2,4,5-$ tetrabromobenzene (TeBB) [48]. Pentabromoethylbenzene (PBEB) is another brominated benzene that is an additive flame retardant. It is produced by Albemarle Corp. and primarily used in circuit boards, textiles, wire coatings, and PUF [40]. No mutagenic or endocrine disrupting properties have been reported for PBEB [3]. Pentabromotoluene (PBT) is also used as an additive flame retardant in similar applications to PBEB. 1,3,5Tribromobenzene (TrBB) is manufactured in China as a BFR; however, annual production data is not available [49]. Very little is known about tetrabromo xylene (TBX) concerning its use and production.

Tetrabromobisphenol A (TBBPA) and its derivates comprise another group of structurally related BFRs. TBBPA is a reactive flame retardant. It is the BFR with the highest production volume on the market and it is used in epoxy and polycarbonate resins. Tetrabromobisphenol A bismethyl ether (TBBPA-BME) and tetrabromobisphenol A bis(2,3dibromopropyl)ether (TBBPA-BDBPE) are additive flame retardants. TBBPA-BDBPE is manufactured under several different brand names such as Saytex HP-800 A and PE-68 [40].

Aliphatic brominated alkanes are another group of structurally related, additive flame retardants. The most prominent compound in this group is $1,2,5,6,9,10$ hexabromocyclododecane (HBCDD). Two other compounds that fall within this group are 1,2,5,6-tetrabromocyclooctane (TBCO) and 1,2-dibromo-4-(1,2-dibromoethyl)cyclohexane (DBE-DBCH, and also abbreviated as TBECH). HBCDD has been used extensively for several decades [50]. Its main application is in polystyrene foam used in building construction. A technical mixture of HBCDD contains three main isomers $(\alpha, \beta$, and $\gamma)$. All three isomers are susceptible to thermal degradation [51]. Although the $\gamma$-isomer is present at the highest concentration in the technical mixture, in biological sample it is usually the $\alpha$-isomer that is found at the highest concentration. It is reported that the $\alpha$-isomer is the least reactive isomer in biological as well as chemical reactions [52, 53]. DBE-DBCH is marketed by Albemarle Corp. as Saytex BCL-462 and contains equal amounts of two stereoisomers ( $\alpha$ - and $\beta$-isomer). TBCO is sold by Albemarle Corp. under the tradename Saytex BCL-48. It contains two stereoisomers that readily interconvert thermally.

Tris(2,3-dibromopropyl)phosphate (TDBPP) is an organophosphate that contains brominated aliphatic alkyl chains. Organophosphates are another large class of flame retardants. There are several chlorinated organophosphates that are in use. TDBPP is the only extensively used brominated organophosphate. It was produced by the Chemische Fabrik Kalk under the name Bromcal P 67-6 HP. It was also known as tris-BP. The compound was reported to be carcinogenic and was banned for use in clothes in the USA [54].

7,8-Dibromo-1,2,3,4,11,11-hexachlorocylo$1,4,4$ a , 5, 6, 7, 8, 9, 10,10 a-d e c a hydro-1,4methanobenzocyclooctene (DBHCTD) is known under the trade name Saytex BC 26 or Citex BC 26. DBHCTD was identified in residential indoor dust in Canada in 2008 [55]. Toxicological data for DBHCTD is lacking. One study evaluates the toxicity and the effect on mRNA expression of DBHCTD in an avian species. No cytotoxicity was detected at the administered concentration range. However, DBHCTD elicit variable mRNA expression responses for the 11 genes assessed [56]. Dibromoaldrin (DBALD) is a flame retardant that was patented in the 1970s. However, there is no information on recent use or production data. DBALD is the brominated form of the insecticide aldrin, which was used until the 1970s when aldrin was banned in most countries. 
Pentabromochlorocyclohexane $(\mathrm{PeBCCH})$ is an additive flame retardant used in polystyrene [57]. $\mathrm{PeBCCH}$ is the main component in a flame retardant mixture known as FR-651 A. The occurrence of $\mathrm{PeBCCH}$ in sediments was reported in 2011 [58]. Tribromotrichlorocyclohexane ( $\operatorname{TrBTrCCH})$ is reported to also be present in FR-651 A along with $\mathrm{PeBCCH}$ [57].

\section{Analysis of BFRs in Sediment and Soils}

\section{Sample Extraction}

There are various methods used for the extraction of BFRs from sediment and soil samples. Soxhlet extraction, accelerated solvent extraction (ASE), also referred to as pressurized solvent extraction (PSE), or ultrasound assisted extraction (UAE) techniques are commonly used. Soxhlet extraction is the oldest and slowest of the three extraction methods. It is usually conducted at least over night (16 h) or for 2 days (40 h). It requires $150-400 \mathrm{~mL}$ of solvent, depending on the size of the Soxhlet apparatus. A mixture of n-hexane/dichloromethane, hexane/acetone, or hexane/dichloromethane/acetone is commonly used. ASE extraction is the newest extraction technology. An ASE apparatus is pressurized and therefore allows extractions at temperatures above the boiling point of the organic solvents (e.g., extraction of sediment sample with dichloromethane at $100{ }^{\circ} \mathrm{C}$ and 120 bar). As a result, the extraction often takes less than $1 \mathrm{~h}$. It requires generally 20 to $40 \mathrm{~mL}$ of solvent. However, the cost of the ASE apparatus along with the required stainless steel extraction cells is a significant initial expense. UAE is the third method that is currently used for sample extraction: Sediment samples are commonly extracted with 10 to $50 \mathrm{~mL}$ organic solvent for 10 to 15 min using an ultrasonic water bath. After sonication, centrifugation separates the sediment and solvent, and the extraction process is repeated twice more. Most work summarized here evaluates the extraction efficiency of the employed extraction method through the use of surrogate standards. Most extraction methods report extraction efficiencies for different BFRs range from 65 to $110 \%$. There seems to be no apparent difference between the three extraction methods insofar as it comes to extraction efficiency. However, the difference in quantity of solvent used, extraction time, and equipment costs are significant.

\section{Sample Clean-up}

All analytical methods summarized here employ a clean-up step after the extraction of the sediment or soil samples. The most common clean-up process involves a liquid-solid chromatographic step with a polar solid-phase (sometimes referred to as solid-phase extraction) that is performed after the sediment extraction. Silica, alumina, and florisil are the regularly employed polar solid-phases. Alternatively, another method uses PestCarb, a graphitized carbon in the clean-up step [59]. Several of the described methods use a combination of two different solid-phases (e.g., silica and florisil, or silica and alumina). In some cases, a multilayer column consists of four to five layers of differently activated silica and alumina $[60,61]$. It is not uncommon to use a multilayer column made up of four different silica layers: $3.5 \%$ water deactivated silica, basic silica, fully activated silica, and acidic silica [62]. A few methods add an additional clean-up step involving gel permeation chromatography (GPC) before or after the column chromatography with silica/alumina [63, 64]. GPC is a type of size exclusion chromatography (SEC). GPC is often used for lipid rich biological samples. A few ASE methods use an incell clean-up by adding silica gel and copper to the extraction cell [65-67]. The advantage of an in-cell clean-up is significant. The sample preparation is significantly shortened since the chromatographic step is no longer necessary and therefore the overall consumption of organic solvents is reduced.

\section{Sample Analysis}

To measure BFR concentrations in the sediment and soil extracts, gas chromatography, or liquid chromatography with MS detector (GC-MS; LC-MS) is utilized [45]. Often tandem mass-spectrometry (MS/MS) is employed, which generally allows lower detection limits. The most common detectors used for BRFs are low resolution massspectrometric detectors (LR-MS). LR-MS allows a nominal mass of a compound to be measured with a plus or minus 0.5 amu degree of accuracy, reporting values to the first decimal place. (In contrast, high resolution-MS measures to four decimal places). LR-MS is cheaper and easier to maintain than high resolution MS. When GC-MS is used, the LR-MS are operated either in electron impact (EI) or in electron capture negative ionization (ECNI) mode. LR-EI-MS provides a higher selectivity than LRECNI-MS, since for the LR-ECNI-MS only the bromine trace can be monitored. However, the detection limit for ECNI-MS is usually lower than for LR-EI-MS. Barón, Eljarrat, and Barceló provide an informative comparison of GC-EI-MS versus GC-EI-MSMS for the analysis of BFRs in sediment samples [67]. Different ionization techniques are also available for LC-MS. The most commonly used ionization technique for LC-MS is electrospray ionization (ESI). However, ESI is subject to sample matrix effects that can cause signal enhancement or signal suppression. For this reason the use of isotopic-labeled standards has become more and more common to compensate for the matrix effects. Atmospheric pressure chemical ionization (APCI) and atmospheric pressure photo ionization 
Table 1 Summary of the methods used to analyze BFRs

\begin{tabular}{|c|c|c|c|c|c|c|}
\hline Authors & Sample $^{\mathrm{a}}$ & Extraction $^{\mathrm{b}}$ & Clean up & Instrumental analysis & & \\
\hline SühringBusch [65] & Sed $\mathrm{m} / \mathrm{r}$ & ASE & in ASE cell & GC-ECNI-MS & GC-EI-MSMS & \\
\hline Olunkunle [59] & Sed 1 & Soxhlet & Silica & GC-EI-MS & & \\
\hline SühringBarber [66] & Sed $\mathrm{m}$ & ASE & In ASE cell & GC-ECNI-MS & GC-EI-MSMS & LC-ESI-MSMS \\
\hline ZhangBayen [68] & Sed & UAE & SEC & GC-EI-MSMS & LC-ESI-MSMS & \\
\hline PeverlyOSullivan [62] & Sed $\mathrm{r}$ & Soxhlet & Multilayer silica & GC-ECNI-MS & & \\
\hline Barber [63] & Sed e/m & Soxhlet & Alumina/silica, SEC & GC-ECNI-MS & LC-MSMS & \\
\hline Lacorte [69] & Sed $\mathrm{r}$ & UAE & Florisil & GC-EI-MSMS & & \\
\hline LamZhu [60] & Sed e & ASE & Alumina/silica & LC-APCI-MSMS & & \\
\hline JangHong [70] & Sed $\mathrm{m}$ & Soxhlet & Silica & LC-APCI-MSMS & & \\
\hline ZhengNizzetto [64] & Soil & Soxhlet & Alumina/silica & GC-ECNI-MS & & \\
\hline ZhangSun [71] & Sed e & Soxhlet & Silica & GC-ECNI-MS & & \\
\hline PomaRoscioli [72] & Sed $\mathrm{r}$ & Soxhlet & Silica/florisil & GC-EI-MS & & \\
\hline ZhuLam [73] & Sed $\mathrm{r} / \mathrm{m}$ & ASE & Silica/alumina & LC-APCI-MSMS & & \\
\hline NewtonSellstroem [74] & Soil & Liq extract & Silica column & GC-ECNI-MS & LC-ESI-MSMS & \\
\hline CasattaMascolo [75] & Sed e & Soxhlet & Silica/florisil & GC-EI-MSMS & LC-ESI-MSMS & LC-APPI-MSMS \\
\hline BaronEljarrat [67] & Sed $\mathrm{r}$ & ASE & In ASE cell & LC-MSMS & & \\
\hline LiuHu [61] & Sed e & Soxhlet & Silica/alumina & GC-ECNI-MS & & \\
\hline LaGuardiaHale [76] & Sed e & ASE & SEC/silica & GC-ECNI-MS & LC-APPI-MSMS & \\
\hline CristaleLacorte [77] & Sed $\mathrm{r}$ & Ultrasonic & Florisil & GC-EI-MSMS & & \\
\hline PeiWu [78] & Sed $\mathrm{r}$ & ASE & Florisil & GC-ECNI-MS & & \\
\hline ZhangBayen [79] & Sed e & UAE & Florisil & GC-EI-MSMS & & \\
\hline WangZhao [49] & Sed e & Soxhlet & Silica & GC-ECNI-MS & & \\
\hline ZhuChenZheng [80] & Soil & Soxhlet & Silica & GC-ECNI-MS & LC-ESI-MSMS & \\
\hline
\end{tabular}

${ }^{\text {a }}$ Sed sediment; $m$ marine; $r$ river; $e$ estuary; $l$ landfill sediment

${ }^{\mathrm{b}} A S E$ accelerated solvent extraction; UAE ultrasonic assisted extraction; liq extract liquid extraction

${ }^{\mathrm{c}} S E C$ size exclusion chromatography

(APPI) are two additional ionization methods that are available.

Most emerging BRFs are currently analyzed alongside major BFRs (e.g., PBDEs, HBCDDs, and TBBPA). While PBDEs are commonly analyzed by GC-MS, HBCDDs, and TBBPA are generally analyzed by LC-MS. (HBCDDs are temperature sensitive and its three main isomers can interconvert on the GC column and therefore cannot be separated by GC). TBBPA is a very polar molecule. Thus, in order to analyze TBBPA by GC it must be derivatized. A derivatization procedure for TBBPA was developed, however the method suffers from incomplete derivatization leading to lower recoveries. Due to the polar nature of the TBBPA molecule, LC-MS seems to be the method of choice. It is known that GC-MS has the advantage of higher sensitivity compared with LC-MS methods. So to improve sensitivity and specificity of LCMS methods for environmental samples, approaches based on LC-tandem MS (MS/MS) have been developed. Table 1 also shows that it is now common to split the sample extract and use different clean-up procedures and different instruments (e.g., GC-MS and LC-MSMS) to detect a multitude of emerging flame retardants.
A comparison of the different analytical methods is of interest; however, such a comparison can be somewhat problematic. Method detection limit (MDL) and limit of detection (LOD) are often reported and can provide insight and might allow a comparison of two analytical methods from different studies. LODs are often calculated from a signal to noise ratio of three. While MDLs are often defined as average blank concentration plus three times the standard deviation. Therefore, a comparison of MDLs between different studies tends to be more influenced by laboratory blank levels than by instrumental capabilities [77]. In addition, MDLs are not always defined in the same way, which makes a comparison of methods from different studies problematic.

\section{BFRs in Sediment and Soil}

Table 2 summarizes the articles that were published from 2013 to 2015 that examined sediment or soil samples for emerging BFRs and notes which BFRs were detected, which compounds were rarely detected (less than $10 \%$ of 
Table 2 Summary of BFRs analyzed and detected

\begin{tabular}{|c|c|c|c|c|c|c|c|c|c|c|c|c|c|c|c|c|c|c|c|c|c|c|c|c|c|c|c|c|}
\hline 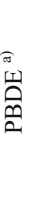 & 嶖 & 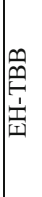 & 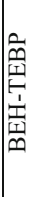 & 嵦 & 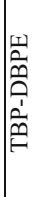 & 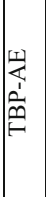 & 这 & $\underset{\bigoplus}{\mathbb{N}}$ & 自 & 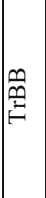 & $\frac{m}{m}$ & 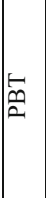 & 希 & $\frac{n}{\frac{n}{10}}$ & 这 & 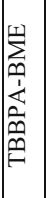 & 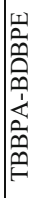 & 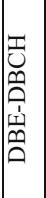 & $\begin{array}{l}0 \\
\bigcup \\
0 \\
1\end{array}$ & 命 & 窟 & 㫕 & 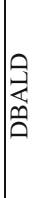 & 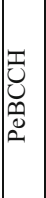 & 芯 & $\frac{0}{\stackrel{0}{0}}$ & 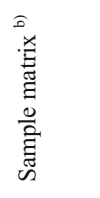 & 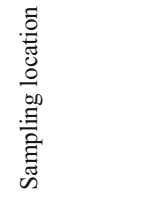 \\
\hline $\mathrm{x}$ & & & & & $\mathrm{x}$ & & & & $\mathrm{x}$ & & & & & & & & & & $\mathrm{x}$ & & & & & & & SühringBusch(65) & $\mathrm{sed} \mathrm{m} / \mathrm{r}$ & Germany \\
\hline & $\mathrm{x}$ & $\mathrm{x}$ & $\mathrm{x}$ & & & & & & & & & & & & & & & & & $\mathrm{x}$ & & & & & & Olukunle(59) & sed 1 & South Africa \\
\hline $\mathrm{x}$ & & $\mathrm{o}$ & & & $\mathrm{x}$ & $\mathrm{o}$ & $\mathrm{o}$ & $\mathrm{x}$ & & & & & & $\mathrm{x}$ & $\mathrm{x}$ & & & & & $\mathrm{x}$ & & & $\mathrm{x}$ & & & SühringBarber(66) & sed $\mathrm{m}$ & UK, Germany \\
\hline $\mathrm{x}$ & & & & $\mathrm{x}$ & & & & & $\mathrm{x}$ & & $\mathrm{n}$ & $\mathrm{n}$ & & $\mathrm{n}$ & $\mathrm{x}$ & & & $\mathrm{n}$ & & $\mathrm{x}$ & & & & & & ZhangBayen(68) & sed & Singapore \\
\hline $\mathrm{x}$ & $\mathrm{x}$ & $\mathrm{x}$ & & $\mathrm{x}$ & & & & & $\mathrm{x}$ & & & & & & & & & & & $\mathrm{x}$ & & & & & & PeverlyOSullivan(62) & sed $r$ & US \\
\hline $\mathrm{x}$ & & o & $\mathrm{n}$ & $\mathrm{x}$ & $\mathrm{n}$ & $\mathrm{n}$ & $\mathrm{n}$ & & $\mathrm{n}$ & & & $\mathrm{x}$ & $\mathrm{x}$ & $\mathrm{x}$ & & $\mathrm{x}$ & & $\mathrm{n}$ & $\mathrm{n}$ & $\mathrm{x}$ & & & & $\mathrm{x}$ & $\mathrm{x}$ & Barber(63) & sed e/m & UK \\
\hline $\mathrm{x}$ & $\mathrm{x}$ & $\mathrm{n}$ & $\mathrm{n}$ & $\mathrm{n}$ & $\mathrm{n}$ & & & & $\mathrm{n}$ & & & & & $\mathrm{n}$ & & & & & & & & $\mathrm{n}$ & & & & Lacorte $(69)$ & $\operatorname{sed~} \mathrm{r}$ & Spain \\
\hline $\mathrm{x}$ & $\mathrm{x}$ & $\mathrm{x}$ & $\mathrm{x}$ & $\mathrm{x}$ & $\mathrm{x}$ & & & & $\mathrm{x}$ & & & $\mathrm{x}$ & & $\mathrm{x}$ & & & & $\mathrm{x}$ & & $\mathrm{x}$ & & $\mathrm{n}$ & & & & LamZhu(60) & sed e & China \\
\hline & & & & $\mathrm{x}$ & & & & & & & & & & & $\mathrm{x}$ & & & & & $\mathrm{x}$ & & & & & & JangHong(70) & sed $\mathrm{m}$ & Korea \\
\hline $\mathrm{x}$ & $\mathrm{x}$ & $\mathrm{x}$ & $\mathrm{x}$ & $\mathrm{x}$ & & & & & $\mathrm{x}$ & & & & & $\mathrm{x}$ & & & & & & & & & & & & ZhengNizzetto(64) & soil & China \\
\hline $\mathrm{x}$ & $\mathrm{x}$ & & & $\mathrm{x}$ & & & & & & & & & & & & & & & & & & & & & & ZhangSun(71) & sed e & China \\
\hline $\mathrm{x}$ & $\mathrm{x}$ & & & $\mathrm{x}$ & & & & & $\mathrm{x}$ & & & & & $\mathrm{o}$ & & & & & & $\mathrm{x}$ & & & & & & PomaRoscioli(72) & sed $r$ & Italy \\
\hline $\mathrm{x}$ & $\mathrm{x}$ & $\mathrm{x}$ & $\mathrm{x}$ & $\mathrm{x}$ & & & & & $\mathrm{n}$ & & & $\mathrm{n}$ & & $\mathrm{n}$ & & & & $\mathrm{x}$ & & $\mathrm{x}$ & & $\mathrm{n}$ & & & & ZhuLam(73) & $\mathrm{sed} \mathrm{m} / \mathrm{r}$ & China \\
\hline $\mathrm{x}$ & $\mathrm{x}$ & $\mathrm{n}$ & $\mathrm{n}$ & $\mathrm{n}$ & & & & & $\mathrm{x}$ & & & $\mathrm{x}$ & & & & & & $\mathrm{n}$ & & $\mathrm{x}$ & & & & & & NewtonSellstroem(74) & soil & Sweden \\
\hline $\mathrm{x}$ & $\mathrm{n}$ & & & & & & & & & & & & & & $\mathrm{x}$ & & $\mathrm{n}$ & & & $\mathrm{x}$ & & & & & & CasattaMascolo(75) & sed e & Italy \\
\hline $\mathrm{x}$ & $\mathrm{x}$ & & & & & & & & $\mathrm{n}$ & & & & & $\mathrm{n}$ & & & & & & & & & & & & BaronEljarrat(67) & sed $r$ & Spain \\
\hline $\mathrm{x}$ & $\mathrm{x}$ & $\mathrm{x}$ & $\mathrm{x}$ & $\mathrm{x}$ & & & & & & & & & & & $\mathrm{x}$ & & & & & $\mathrm{x}$ & $\mathrm{x}$ & $\mathrm{x}$ & & $\mathrm{x}$ & & $\mathrm{LiuHu}(61)$ & sed e & China \\
\hline $\mathrm{x}$ & $\mathrm{x}$ & $\mathrm{x}$ & $\mathrm{x}$ & $\mathrm{x}$ & & & & & & & & & & & & & & & & $\mathrm{x}$ & & & & & & LaGuardiaHale(76) & sed e & South Africa \\
\hline $\mathrm{x}$ & $\mathrm{x}$ & $\mathrm{n}$ & $\mathrm{n}$ & $\mathrm{n}$ & $\mathrm{n}$ & & & & $\mathrm{n}$ & & & $\mathrm{n}$ & & $\mathrm{n}$ & & & & & & & & $\mathrm{n}$ & & & & CristaleLacorte (77) & sed $r$ & Spain \\
\hline $\mathrm{x}$ & $\mathrm{x}$ & $\mathrm{x}$ & $\mathrm{x}$ & $\mathrm{x}$ & & & & & & & & & & & & & & & & & & & & & & PeiWu(78) & sed $r$ & China \\
\hline $\mathrm{x}$ & & & & $\mathrm{O}$ & & & & & $\mathrm{x}$ & 0 & 0 & $\mathrm{n}$ & & $\mathrm{n}$ & & & & $\mathrm{n}$ & & & & & & & & ZhangBayen(79) & sed e & Singapore \\
\hline & & & & & & & & & & $\mathrm{x}$ & & $\mathrm{x}$ & $\mathrm{x}$ & $\mathrm{x}$ & & & & & & & & & & & & WangZhao(49) & sed e & China \\
\hline $\mathrm{x}$ & $\mathrm{x}$ & & & & & & & & $\mathrm{x}$ & & & & & & $\mathrm{x}$ & & & & & $\mathrm{x}$ & & & & & & ZhuChenZheng $(80)$ & soil & China \\
\hline
\end{tabular}

${ }^{\text {a }} x$ frequently detected; $o$ detected in less than $10 \%$ of samples; $n$ not detected

${ }^{\mathrm{b}} \mathrm{Sed}$ sediment; $m$ marine, $r$ river, $e$ estuary, $l$ landfill sediment

the samples), and which compounds were analyzed but not detected in any samples of a particular study. It is not surprising that PBDEs were found in all studies that were analyzing for them. The same is true for HBCDDs and TBBPA. This ubiquitous presence of PBDEs, HBCDDs, and TBBPA can be easily explained by their widespread use for several decades. BTBPE and DBDPE were also detected in most samples. Their reported concentrations in the reviewed articles were generally lower than those for PBDEs. EH-TBB was detected in about $75 \%$ of the studies that analyzed for the compound. BEH-TEBP was detected in about $60 \%$ of the studies. BEH-TEBP was reported in some sediment samples from China and Europe as well as in soil samples in China. TBP-DBPE was found in three out of six studies. TBP-AE was reported in one out of two studies, while BATE was only detected in a few samples in one study. HBB was analyzed in 13 studies. About two thirds of those studies report HBB in their samples. Other brominated benzenes such as PBEB and PBT are found in about half of the studies looking for those compounds. $\mathrm{TBX}, \mathrm{TrBB}$, and TeBB were only reported in one or two studies, respectively. DBE-DBCH is reported in two out of six studies analyzing for the compound. TBCO was found in one out of two studies. TBBPA-DME was detected in the one study that was analyzing for it. TBBPA-BPBPE was analyzed in one study and it was not detected in any samples of that study. There were five studies that report on the analysis for DBHCTD, however only one study was able to detect the compound in sediment samples. DBALD was detected in the one study that analyzed for it. PeBCCH was detected in two out of two investigations, while $\mathrm{TrBTrCCH}$ was reported in sediments in the one study that analyzed for it. Several studies that analyzed samples from several regions conclude that proximity of point sources or population centers affects the measured concentrations [61, $64,71,73,74]$.

\section{Studies in Africa}

There are two studies reporting the analyses of BFRs in sediments from South Africa in the past 3 years. La Guardia, Hale, and Newman analyzed marine samples from Durban Bay [76]. $\angle$ PBDE is reported at a mean concentration about twice as high as the mean concentration for HBCDDs. EHTBB was the emerging BFR reported at the highest mean concentration, followed by DBDPE, EH-TEBP, and BTBPE. Olukunle and Okonkwo analyzed sediments from municipal landfills in South Africa [59]. The reported mean concentrations for HBCDDs, EH-TBB, BTBPE, and BEH-TEBP were all in range of 10 to $51 \mathrm{ng} / \mathrm{g}$. DPDPE was not recovered with the method employed and could therefore not be determined. 


\section{Studies in Asia}

Jang et al. analyzed marine sediment samples from two coastal regions in South Korea for HBCDDs, TBBPA, and BTBPE [70]. The reported mean concentration for HBCDDs was $9.8 \mathrm{ng} / \mathrm{g}$, while the mean concentration for BTBPE was $3.2 \mathrm{ng} / \mathrm{g}$. The reported mean concentration for TBBPA was $0.29 \mathrm{ng} / \mathrm{g}$. Zhang et al. report the concentration of $\Sigma \mathrm{PBDE}$, DBDPE, and BTBPE in mangrove sediments samples collected in three different locations in South China [71]. The authors observed spatial dependence of the concentrations to the proximity of the sampling location to urban areas. The concentrations of $\angle$ PBDEs were 3-5 times larger than the measured concentration for DBDPE. The concentrations for BTBPE were about eight times lower than the concentration for DBDPE. A sediment core analysis revealed that the concentrations for DBDPE and BTBPE were the highest at the surface as is expected for a compound with rapidly increasing use. Zhu and coworkers determined the occurrence of 11 alternate BFRs in sediments in the Yangtze River Delta region in China [80]. The reported mean concentrations of $\angle$ PBDEs in marine sediments was $1.37 \mathrm{ng} / \mathrm{g}$, for DBDPE was $0.471 \mathrm{ng} /$ $\mathrm{g}$, and for HBCDDs $0.047 \mathrm{ng} / \mathrm{g}$. The authors also detected DBE-DBCH, a novel BFR that has not been analyzed frequently in studies. A mean concentration of $0.844 \mathrm{ng} / \mathrm{g}$ was reported. This mean concentration was higher than for DBDPE. The concentration of the other emerging BFRs was below the detection limit in the marine sediment samples. The river sediments that were analyzed as part of the same study showed concentrations that were 3-10 times larger than the mean concentration in the marine sediment samples. The mean concentrations in the river sediments were $1.01 \mathrm{ng} / \mathrm{g}$ BEH-TEBP, 0.403 ng/g EH-TBB, and $0.0223 \mathrm{ng} / \mathrm{g}$ BTBPE, respectively. Liu and coworkers report the concentration of BFRs in sediments off an urbanized coastal zone in China [61]. The study reports a mean concentration for $\angle \mathrm{PBDE}$ of $0.770 \mathrm{ng} / \mathrm{g}$. The concentration for DBDPE and HBCDDs were in the same range as the concentration for $\angle \mathrm{PBDE}$. The concentration for TBBPA and BTBPE were about two times lower. The work also found EH-TBB and EH-TEBP in all samples from $0.044-0.680 \mathrm{ng} / \mathrm{g}$ and $0.047-0.740 \mathrm{ng} / \mathrm{g}$, respectively. This study also reports the detection of three novel BFRs that have not been frequently analyzed or detected: $\mathrm{PBCCH}$ was found at concentrations from 0.13 to $2.0 \mathrm{ng} /$ $\mathrm{g}$, in addition TDBPP and HBDBCO were detected in some samples at concentrations up to $0.20 \mathrm{ng} / \mathrm{g}$ and $0.21 \mathrm{ng} / \mathrm{g}$, respectively. Zheng et al. measured the concentration of 16 flame retardants (FRs) in forest soil samples in China [64]. The mean concentration of total PBDEs is $0.92 \mathrm{ng} / \mathrm{g}$ for Ohorizon soil samples. DPDPE is the emerging BFR at the highest concentration measured $(2.64 \mathrm{ng} / \mathrm{g})$. The remaining set of emerging BRFs was present at lower mean concentrations. EH-TBEP: $0.251 \mathrm{ng} / \mathrm{g}$, BEH-TBPH: $0.132 \mathrm{ng} / \mathrm{g}$,
BTBPE: 0.049 ng/g, HBB: 0.046 ng/g, PBEB: 0.007 ng/g. Zhu et al. report the concentration of BFRs in agricultural soils in North China [80]. The mean concentration reported were $275 \mathrm{ng} / \mathrm{g}$ for $\Sigma$ BFRs, $66.4 \mathrm{ng} / \mathrm{g}$ for DBDPE, $107 \mathrm{ng} / \mathrm{g}$ for TBBPA, and $8.93 \mathrm{ng} / \mathrm{g}$ for HBCDDs, respectively.

\section{Studies in Europe}

The works by Sühring and Barber measure BFRs in marine sediments from the North Sea of the coast of Germany and the UK $[63,65,66]$. The concentrations in general were low for most compounds analyzed. Many compounds could only be detected semi-quantitatively with concentrations often less than $0.10 \mathrm{ng} / \mathrm{g}$ dry weight. An exception was the comparably high concentration of TBBPA at sampling sites from the north east coast of England that ranged between $<\mathrm{LOD}$ and $6.40 \mathrm{ng} / \mathrm{g}$. Overall FR concentrations were higher in samples from the UK coast than samples from Germany. The authors explain that due to stricter fire safety regulation in Britain, FRs are used more heavily. Detection frequency of individual emerging BFRs varied significantly with sampling sites in all three studies. Concentrations of emerging BFRs were in similar range as PBDEs, indicating that the emerging BFRs are replacing PBDEs as contaminants in the North Sea sediments. However, from the data, it is not apparent which are the dominant FRs currently in use to replace PBDEs. Casatta and coworkers analyzed estuarine sediment samples from the Adriatic Sea in Northern Italy [75]. The concentrations for $\Sigma$ PBEDs was $12 \mathrm{ng} / \mathrm{g}$, the average concentration of HBCDDs was $0.13 \mathrm{ng} / \mathrm{g}$, while the concentration for DPDPE was below the LOD of $5 \mathrm{ng} / \mathrm{g}$.

There are several studies examining BFR concentrations in river/lake sediments in Europe. Poma and coworkers measured the concentration of BFRs in lake sediment from Northern Italy [72]. The concentrations for BTBPE, HBB, and PDEB were relatively low $(<0.2 \mathrm{ng} / \mathrm{g})$. HBCDDs were measured at concentrations $4.7 \mathrm{ng} / \mathrm{g}$ and DBDPE was determined at concentrations of up to $19.7 \mathrm{ng} / \mathrm{g}$. The analysis of a sediment core demonstrates the increase of DBDPE since 1989. Barón, Eljarrat, and Barceló reported the concentrations of some BFRs in river sediment samples from Spain [67]. The concentrations for $\Sigma$ PBDE and DBDPE were in a similar concentration range (30-40 ng/g). HBB and PBED were not detected. The reported MDLs for these compounds are $0.030 \mathrm{ng} / \mathrm{g}$ and $0.040 \mathrm{ng} / \mathrm{g}$, respectively.

The study by Newton, Sellström, and de Wit reports the concentration of BFRs in soil samples from Sweden [74]. PBDEs, HBCDDs, and DBDPE are detected in all soils samples and at comparable concentrations (around $1 \mathrm{ng} / \mathrm{g}$ organic matter). PBT and HBB were detected in several samples at concentrations of $0.020 \mathrm{ng} / \mathrm{g}$ organic matter and $0.070 \mathrm{ng} / \mathrm{g}$, respectively. 


\section{Discussion}

The detection of emerging BFRs in sediments and soil is an important tool to determine the environmental behavior of these compounds. However, the determination of the concentration of emerging BFRs in sediments and soils is still a rather challenging analytical task. Methods that were developed for the analyses of PBDEs, TBBPA, and other BFRs are now adapted in order to detect the emerging BFRs in sediments. Since BFRs consists of a rather diverse group of compounds, it seems necessary to use different analytical methods (e.g., GC-MS and LC-MSMS) to detect as many emerging BFRs as possible.

From the reviewed studies it might be concluded that DBDPE has emerged as a replacement for PBDEs. DBDPE is now detected consistently at concentrations comparable to PBDEs in surficial sediments in Asia. Some other alternate BFRs (e.g., EH-TBB, BEH-TEBP, BTBPE) are also detected often. However, their concentrations and their frequency of detection in soil or sediment samples are currently lower than for DBDPE.

Acknowledgments I would like to thank Xianmiao Zhang for her invaluable help by translating the articles that were published in Chinese and Dr. Rudolph for her assistance with the manuscript. I would also like to thank the reviewers for their comments.

\section{Compliance with Ethical Standards}

Conflict of Interest The authors have no conflict of interest.

Human and Animal Rights and Informed Consent This article does not contain any studies with human or animal subjects performed by the author.

\section{References}

1. Arcadis Evaluation of data on flame retardants in consumer products. Final report to the European Commission. http://ec.europa. eu/consumers/archive/safety/news/flame_retardant_substances study_en.pdf, 2011.

2. Yu G, Bu Q, Cao Z, Du X, Xia J, Wu M, Huang J. Brominated flame retardants (BFRs): a review on environmental contamination in China. Chemosphere. 2016;150:479-90.

3. Harju M, Heimstad ES, Herzke D, Sandanger T, Posner S, Wania F. Emerging "new" Brominated flame retardants in flame retarded products and the environment; http://www.miljodirektoratet. no/old/klif/publikasjoner/2462/ta2462.pdf; Norwegian Pollution Control Authority, Report 2462: Oslo, Norway, 2009.

4. Quinn CL, van der Heijden SA, Wania F, Jonker MTO. Partitioning of polychlorinated biphenyls into human cells and adipose tissues: evaluation of octanol, triolein, and liposomes as surrogates. Environ Sci Technol. 2014;48:5920-8.

5. Mackay D, Fraser A. Bioaccumulation of persistent organic chemicals: mechanisms and models. Environ Pollut. 2000;110: 375-91.

6. U.S.EPA An alternatives assessment for the flame retardant decabromodiphenyl ether (DecaDBE); United States Enviromental Protection Agency: 2014.
7. Pijnenburg AMCM, Everts JW, de Boer J, Boon JP. Polybrominated biphenyl and diphenylether flame retardants: analysis, toxicity, and environmental occurrence. Springer. 1995;141: $1-26$.

8. de Wit CA. An overview of brominated flame retardants in the environment. Chemosphere. 2002;46:583-624.

9. Alaee M, Arias P, Sjödin A, Bergman A. An overview of commercially used brominated flame retardants, their applications, their use patterns in different countries/regions and possible modes of release. Environ Int. 2003;29:683-9.

10. Birnbaum LS, Staskal DF. Brominated flame retardants: cause for concern? Environ Health Perspect. 2004;112:9-17.

11. Law RJ, Allchin CR, de Boer J, Covaci A, Herzke DPL, Morris S, Tronczynski J, de Wit CA. Levels and trends of brominated flame retardants in the European environment. Chemosphere. 2006;64: 187-208.

12. Tananbe S, Ramu K, Isobe T, Takahashi S. Brominated flame retardants in the environment of Asia-Pacific: an overview of spatial and temporal trends. J Environ Monit. 2008;10:188-97.

13. Law RJ, Herzke D, Harrad S, Morris S, Bersuder P, Allchin CR. Levels and trends of HBCD and BDEs in the European and Asian environments, with some information for other BFRs. Chemosphere. 2008;73:223-41.

14. Yogui GT, Sericano JL. Polybrominated diphenyl ether flame retardants in the U.S. marine environment: a review. Environ Int. 2009;35:655-66.

15. Daso AP, Fatoki OS, Odendaal JP, Okonkwo JO. A review on sources of brominated flame retardants and routes of human exposure with emphasis on polybrominated diphenyl ethers. Environ Rev. 2010;18:239-54.

16. de Wit CA, Herzke D, Vorkamp K. Brominated flame retardants in the Arctic environment- trends and new candidates. Sci Total Environ. 2010;408:2885-918.

17. Marvin CH, Tomy G, Armitage JM, Arnot JA, McCarty L, Covaci A, Place V. Hexabromocyclododecane: current understanding of chemistry, environmental fate and toxicology and implications for global management. Environ. Sci. Technol. 2011;45:8613-23.

18. Besis A, Samara C. Polybrominated diphenyl ethers (PBDEs) in the indoor and outdoor environments - a review on occurrence and human exposure. Environ Pollut. 2012;169:217-29.

19. Law RJ, Covaci A, Harrad S, Herzke D, Abdallah MA-E, Fernie K, Toms L-ML, Takigami H. Levels and trends of PBDEs and HBCDs in the global environment: status at the end of 2012. Environ Int. 2014;65:147-58.

20. Safe S, Kohli J, Crawford A, FireMaster BP-6: fractionation, metabolic and enzyme induction studies. Environ Health Perspect. 1978;23:147-52.

21. Di Carlo FJ, Seifter J, De Carlo VJ. Assessment of the hazards of polybrominated biphenyls. Washington DC: US EPA; 1978. p. 120.

22. Venier M, Salamova A, Hites RA. Halogenated flame retardants in the Great Lakes environment. Acc Chem Res. 2015;48:1853-61.

23. Hesse JL, Powers RA. Polybrominated biphenyl (PBB) contamination of the Pine River, Gratiot and Midland Counties, Michigan. Environ Health Perspect. 1978;23:19-25.

24. Hites RA. Polybrominated diphenyl ethers in the environment and in people: a meta-analysis of concentrations. Environ. Sci. Technol. 2004;38:945-56.

25. U.S.EPA DecaBDE phase-out initiative. https://hero.epa. gov/hero/index.cfm/reference/download/.../1003362. Accessed 18 Jul 2016.

26. UNEP. http://chm.pops.int/Countries/StatusofRatifications/ PartiesandSignatoires/t45/4500/Default.aspx. Accessed 18 Jul 2016. 
27. Stockholm Convention on Persistent Organic Pollutants Amendment to Annex A. https://trea/doc/Publication/CN/2013 /CN.934.2013-Eng.pdf. Accessed 14 Jul 2016.

28. BSEF Bromine Science and Environmental Forum. www.bsef.com. Accessed 30 Mar 2016.

29. Bergman A, Ryden A, Law RJ, de Boer J, Covaci A, Alaee M, Birnbaum L, Petreas M, Sakai S, Van Den Eede N, van der Veen I. A novel abbreviation standard for organobromine, organochlorine and organophosphorus flame retardants and some characteristics of the chemicals. Environ Int. 2012;49:57-82.

30. Kierkegaard A, Björklund J, Fridén U. Identification of the flame retardant decabromodiphenyl ethane in the environment. Environ Sci Technol. 2004;38:3247-53.

31. Nakari T, Huhtala S. In vivo and in vitro toxicity of decabromodiphenyl ethane, a flame retardant. Environ Toxicol. 2010;25:333-8.

32. Kohn M, Fink A. Über einige Bromderivate des Phenols und die Beweglichkeit der Bromatome in denselben. Monatsh Chem. 1923;44:183-95.

33. Tomy G, Place VP, Pleskach K, Ismail N, Oswald T, Danell R, Wautier K. Dietary exposure of juvenile rainbow trout (Oncorhynchus mykiss) to 1,2-bis(2,4,6-tribromophenoxy)ethane: bioaccumulation parameters, biochemical effects, and metabolism. Environ. Sci. Technol. 2007;41:4913-8.

34. Zweidinger RA, Cooper SD, Eriksson MD, Michael LC, Pellizzari ED. Sampling and analysis for semivolatile brominated organics in ambient air. American Chemical Society. 1979; 94.

35. Sjödin A, Carlsson H, Thuresson K, Sjolin S, Bergman A, Ostman C. Flame retardants in indoor air at an electronics recycling plant and at other work environments. Environ Sci Technol. 2001;35: $448-54$.

36. Hoh E, Zhu LY, Hites RA. Novel flame retardants, 1,2-bis(2,4,6tribromophenoxy)ethane and 2,3,4,5,6-pentabromoethyl benzene in United States' environmental samples. Environ Sci Technol. 2005:39:2472-7.

37. Ezechias M, Svobodova K, Cajthaml T. Hormonal activities of new brominated flame retardants. Chemosphere. 2012;87:820-4

38. Johnson PI, Stapleton HM, Mukherjee B, Hauser R, Meeker JD. Associations between brominated flame retardants in house dust and hormone levels in men. Sci Total Environ. 2013;445:177-84.

39. Von der Recke R, Vetter W. Synthesis and characterization of 2,3dibromopropyl-2,4,6-tribromophenyl ether (DPTE) and structurally related compounds evidenced in seal blubber and brain. Environ Sci Technol. 2007:41:1590-5.

40. Covaci A, Harrad S, Abdallah MA-E, Ali N, Law RJ, Herzke D, de Wit CA. Novel brominated flame retardants: a review of their analysis, environmental fate and behavior. Environ Intern. 2011;37: 532-56.

41. Olsen CM, Meussen-Elhom ETM, Holme JA, Hongslo JK. Brominated phenols: characterization of estrogen-like activity in the human breast cancer cell-line MCF-7. Toxicol Lett. 2002;129: 55-63.

42. Vetter W. Marine halogentated natural products of environmental relevance. Springer. 2006;188:1-57.

43. Stapleton HM, Klosterhaus S, Eagle S, Fuh J, Meeker JD, Blum A, Webster TF. Detection of organophosphate flame retardants in furniture foam and U.S. house dust. Environ Sci Technol. 2009;43: $7490-5$.

44. Andersson PL, Öberg K, Örn U. Chemical characterization of brominated flame retardants and identification of structurally representative compounds. Env Tox Chem. 2006;25:1275-82.

45. Eljarrat E, Barcelo D. Brominated flame retardants. Berlin Heidelberg: Springer; 2011

46. Watanabe I, Sakai S. Environmental release and behavior of brominated flame retardants. Environ Int. 2003;29:665-82.
47. Yamaguchi Y, Kawano M, Tatsukawa R. Tissue distribution and excretion of hexabromobenzene and its debrominated metabolites in the rat. Arch Environ Contam Toxicol. 1988;17:807-12.

48. Yamaguchi Y, Kawano M, Tatsukawa R. Hexabromobenzene and its debromination compounds in human adipose tissues of Japan. Chemosphere. 1988;17:703-7.

49. Wang L, Zhao Q, Zhao Y, Zheng M, Lou Y, Yang B. New nonPBDE brominated flame retardants in sediments and plant samples in Jiazhou Bay wetland. Mar Poll Bull. 2015;97:512-7.

50. Covaci A, Gerecke AC, Law RJ, Voorspoels S, Kohler M, Heeb NV, Leslie H, Allchin C, de Boer J. Hexabromocyclododecanes (HBCDs) in the environment and humans: a review. Environ Sci Technol. 2006;40:3679-88.

51. Barontini F, Cozzani V, Cuzzola A, Petara L. Investigation of hexabromocyclododecane thermal degradition pathways by gas chromatography/mass spectrometry. Rapid Comm Mass Spectrom. 2001;15:690-8.

52. Hakk H, Szabo DT, Huwe J, Diliberto J, Birnbaum L. Novel and distinct metabolites identified following a single oral dose of $\alpha$ - or $\gamma$-hexabromocyclododecane in mice. Environ. Sci. Technol. 2012;46:13494-503.

53. Lo KW, Saha-Roy SC, Jans U. Investigation of the reaction of hexabromocyclododecane with polysulfide and bisulfide in methanol/water solutions. Chemosphere. 2012;87:158-62.

54. Blum A, Gold MD, Ames BN, Jones FR, Hett EA, Dougherty RC, Horning ED, Dzidic I, Carroll DI, Stillwell RN, Thenot JP. Children absorb tris-BP flame retardant from sleepwear: urine contains the mutagenic metabolite 2,3-dibromopropanol. Science. 1978;201: 1020-3.

55. Zhu J, Hou Y, Feng Y-L, Shoeib M, Harner T. Identification and determination of hexachlorocylcopenadienyl-dibromocyclooctane (HCDBCO) in residential indoor air and dust: a previoulsy unreported halogenated flame retardant in the environment. Environ. Sci. Technol. 2008;42:386-91.

56. Egloff C, Crump D, Chiu S, Manning G, McLaren KK, Cassone CG, Letcher RJ, Gauthier LT, Kennedy SW. In vitro and in ovo effects of four brominated flame retardants on toxicity and hepatic mRNA expression in chicken embryos. Toxicol Lett. 2011;207:25-33.

57. Lickly TD, Rhinehart WL, Murphy RG, Mendoza CG. Aerobic and anaerobic soil degradation of a hexahalocyclohexane mixture. Environ Tox Chem. 1984;3:503-10.

58. Lopez P, Brandsma SA, Leonards PEG, de Boer J. Optimization and development of analytical methods for the determination of new brominated flame retardants and polybrominated diphenyl ethers in sediments and suspended particulate matter. Anal Bioanal Chem. 2011;400:871-83.

59. Olukunle OI, Okonkwo JO. Concentration of novel brominated flame retardants and $\mathrm{HBCD}$ in leachates and sediments for selected municipal solid water landfill sited in Gauteng Province, South Africa. Waste Manag. 2015;43:300-6.

60. Lam JCW, Zhu BZ, Lai NLS, Xia CH, Yang SY, Li XL, Lam PKS. Emerging halogenated flame retardants in coastal region of China. Organohalogen Compd. 2013;75:1269-72.

61. Liu H-H, Hu Y-J, Luo P, Bao L-J, Qiu J-W, Leung KMY, Zeng EY. Occurrence of halogenated flame retardants in sediments off an urbanized coastal zone: association with urbanization and industrialization. Environ. Sci. Technol. 2014;48:8465-73.

62. Peverly AA, O'Sullivan C, Liu L-Y, Venier M, Martinez A, Hornbuckle KC, Hites RA. Chicago's sanitary and ship canal sediment: polycyclic aromatic hydrocarbons, polychlorinated biphenyl, brominated flame retardants, and organophosphate esters. Chemosphere. 2015;134:380-6.

63. Barber JL, Losada S, Bersuder P, Maes T, Bolam S, Lyons B, Law RJ. Halogenated flame retardants in UK sediments. Organohalogen Compd. 2014;76:1348-51. 
64. Zheng Q, Nizzetto L, Li J, Mulder MD, Sanka O, Lammel G, Bing H, Liu X, Jiang Y, Luo C, Zhang G. Spatial distribution of old and emerging flame retardants in Chinese forest soils: sources, trends and processes. Environ Sci Technol. 2015;49:2904-11.

65. Sühring R, Busch F, Fricke N, Kötke D, Wolschke H, Ebinghaus R. Distribution of brominated flame retardants and dechloranes between sediments and bentic fish - a comparison of a freshwater and marine habitat. Sci Total Environ. 2016;542:578-85.

66. Sühring R, Barber JL, Wolschke H, Kötke D, Ebinghaus R. Fingerprint analysis of brominated flame retardants and dechloranes in North Sea sediments. Environ Res. 2015;140:569-78.

67. Baron E, Eljarrat E, Barcelo D. Gas chromatography/tandem mass spectrometry method for the simultaneous analysis of 19 brominated compounds in environmental and biological samples. Anal Bioanal Chem. 2014;406:7667-76.

68. Zhang H, Bayen S, Kelly BC. Co-extraction and simultaneous determination of multi-class hydrophobic organic contaminants in marine sediments and biota using GC-EI-MS/MS and LC-ESIMS/MS. Talanta. 2015;143:7-18.

69. Lacorte S, Cristale J, Hurtado A, Bertolero A, Ramos D, van Drogge B. Distribution and prevalence of PBDEs, organophosphorus and new brominated flame retardants in environmental samples. Organohalogen Compd. 2014;76:1411-4.

70. Jang M, Hong SH, Han GM, Rani M, Shim WJ. Occurrence of brominated flame retardants in the sediments from industrialized coastal regions of South Korea. Organohalogen Compd. 2013;75: $111-4$.

71. Zhang Z-W, Sun Y-X, Sun K-F, Xu X-R, Yu S, Zheng T-L, Luo XJ, Tian Y, Hu Y-X, Diao Z-H, Mai B-X. Brominated flame retardants in mangrove sediments of the Pearl River Estuary, South China: spatial distribution, temporal trend and mass inventory. Chemosphere. 2015;123:26-32.

72. Poma G, Roscioli C, Guzzella L. PBDE, HBCD, and novel brominated flame retardants contamination in sediments from Lake
Maggiore (Nothern Italy). Environ Monit Assess. 2014;186: 7683-92.

73. Zhu B, Lam JCW, Yang S, Lam PKS. Conventional and emerging halogenated flame retardants (HFRs) in sediment of Yantze River Delta (YRD) region, East China. Chemosphere. 2013;93:555-60.

74. Newton S, Sellström U, de Wit CA. Emerging flame retardants, PBDEs, and HBCDDs in indoor and outdoor media in Stockhom, Sweden. Environ Sci Technol. 2015;49:2912-20.

75. Casatta N, Mascolo G, Roscioli C, Vigano L. Tracing endocrine disrupting chemicals in coastal lagoon (Sacca di Goro, Italy): sediment contamination and bioaccumulation in Manila clams. Sci Total Environ. 2015;511:214-22.

76. La Guardia M, Hale RC, Newman B. Brominated flame-retardants in Sub-Saharan Africa: burdens in inland and coastal sediments in the eThekwini metropolitan municipality, South Africa. Environ. Sci. Technol. 2013;47:9643-50.

77. Cristale J, Lacorte S. Development and validation of a multiresidue method for the analysis of polybrominated diphenyl ethers, new brominated and organophosphorus flame retardants in sediment, sludge and dust. J Chromatogr A. 2013;1305:267-75.

78. Pei J-H, Wu M-H, Xiang J-J, Peng B-Q, Xu G, Sun Y-F, Gu J-Z, Lei $\mathrm{J}-\mathrm{Q}$. Determination of four kinds of novel brominated flame retardants in sediments by gas chromatography-mass spectrometry combined with accelerated solvent extraction-synchronous purification. Fenxi Ceshi Xuebao (Journal of Instrumental Analysis). 2014;33: 773-9.

79. Zhang H, Bayen S, Kelly BC. Multi-residue analysis of legacy POPs and emerging organic contaminants in Singapore's coastal waters using gas chromatography-triple quadrupole tandem mass spectrometry. Sci Total Environ. 2015;523:219-32.

80. Zhu Z-C, Chen S-J, Zheng J, Tian M, Feng A-H, Luo X-J, Mai B$\mathrm{X}$. Occurrence of brominated flame retardants (BFRs), organochlorine pesticides (OCPs), and polychlorinated biphenyls (PCBs) in agricultural soils in a BFR-manufacturing region of North China. Sci Total Environ. 2014;481:47-54. 